\title{
Development and validation of an HPLC method for the determination of fluorouracil in polymeric nanoparticles
}

\author{
Ana Cristina de Mattos, Najeh Maissar Khalil, Rubiana Mara Mainardes*
}

Department of Pharmacy, Midwestern State University/UNICENTRO, Guarapuava, Paraná, Brasil

\begin{abstract}
The objective of this work was to develop and validate a rapid high performance liquid chromatography (HPLC) method for the quantitative analysis of fluorouracil (5-FU) in polymeric nanoparticles. Chromatographic analyses were performed on an RP C18 column with a mobile phase consisting of acetonitrile and water $(10: 90, \mathrm{v} / \mathrm{v})$ at a flow rate of $1 \mathrm{~mL} / \mathrm{min}$. The $5-\mathrm{FU}$ was detected and quantitated using a photodiode array detector at a wavelength of $265 \mathrm{~nm}$. The method was shown to be specific and linear in the range of $0.1-10 \mu \mathrm{g} / \mathrm{mL}(\mathrm{r}=0.9997)$. The precision (intra- and inter-day) was demonstrated because the maximum relative standard deviation was $3.51 \%$. The method is robust relative to changes in flow rate, column and temperature. The limits of detection and quantitation were 10.86 and $32.78 \mathrm{ng} / \mathrm{mL}$, respectively. The method fulfilled the requirements for reliability and feasibility for application to the quantitative analysis of 5-FU in polymeric nanoparticles.
\end{abstract}

Uniterms: Fluorouracil/determination. Nanoparticles. High performance liquid chromatography/ quantitative analysis/method validation.

\begin{abstract}
O objetivo deste trabalho foi desenvolver e validar um método rápido de cromatografia líquida de alta eficiência (CLAE) para análise quantitativa de fluorouracila (5-FU) em nanopartículas poliméricas. Corridas cromatográficas foram realizadas sob uma coluna RP C18 com uma fase móvel consistindo de acetonitrila e água $(10: 90, \mathrm{v} / \mathrm{v})$ a um fluxo de $1 \mathrm{~mL} / \mathrm{min}$. O 5-FU foi detectado e quantificado através de um detector de fotodiodos em um comprimento de onda de $265 \mathrm{~nm}$. O método demonstrou ser específico e linear na faixa de $0,1-10 \mu \mathrm{g} / \mathrm{mL}(\mathrm{r}=0.9997)$. As precisões (intra e inter dia) revelaram um desvio padrão relativo máximo de $3,51 \%$. O método é robusto considerando mudanças realizadas no fluxo da fase móvel, temperatura e marca da coluna. Os limites de detecção e quantificação foram de 10,86 e $32,78 \mathrm{ng} / \mathrm{mL}$, respectivamente. O método cumpriu os requisitos para ser considerado confiável e viável para aplicação na análise quantitativa de 5-FU em nanopartículas poliméricas.
\end{abstract}

Unitermos: Fluorouracila/determinação. Nanopartículas. Cromatografia líquida de alta eficiências/ análise quantitativa/validação de método.

\section{INTRODUCTION}

The fluorouracil (5-FU) is an anticancer agent used in the treatment of solid tumors. This drug, an analog of the natural pyrimidine uracil, must be converted to the nucleotide to exert its effect. The drug is rapidly metabolized after administration, giving cytotoxic fluoronucleotides with well-known antineoplastic properties (Pinedo, Peters, 1988). One explanation for this phenomenon is the possi-

*Correspondence: R. M. Mainardes. Departamento de Farmácia, Universidade Estadual do Centro-Oeste/UNICENTRO. Rua Simeão Camargo Varela de Sá 03, 85040-080 - Guarapuava - PR, Brasil. E-mail: rubianamainardes@hotmail.com bility that 5-FU pharmacomodulation markedly increases the antitumor efficacy of this antimetabolite (Peters, Van Groeningein, 1991).

The mechanism of 5-FU cytotoxicity is complex because the drug is activated through different pathways leading to at least three cytotoxic compounds: fluorodeoxyuridine monophosphate, which inhibits thymidylate synthase and subsequent DNA synthesis; fluorouridine triphosphate, which is directly incorporated into RNA; and fluorodeoxyuridine triphosphate, for which incorporation into DNA has been suggested (Grem, 1990).

The 5-FU presents a narrow therapeutic index, and many papers have reported greater variability in pharma- 
cokinetics than other anticancer drugs. For these reasons, some inter-patient differences in terms of toxicity and efficacy can be expected based on individual pharmacokinetic parameters, especially in the area under the time $v s$. concentration curve (AUC) (Gamelin, Boisdron-Celle, 1999; Gamelin et al., 1999; Casale et al., 2004). Another problem with 5-FU therapy is its toxicity to the bone marrow and the gastrointestinal tract (Tanaka et al., 2000; Lai, Guo, 2011). Therefore, 5-FU represents an interesting drug model to be improved by nanotechnology.

Numerous investigators have shown that the biological distribution of drugs, proteins or DNA can be modified, both at the cellular and organ levels, using micro/ nanoparticle delivery systems (Moghimi et al., 2001; Panyam, Labhasetwar, 2003; Labhasetwar, Prabha, 2004; Akagi et al., 2005). The nanoencapsulation of drugs has many advantages for the protection from premature degradation and interaction with the biological environment, enhancement of absorption into a selected tissue, bioavailability, retention time and improvement of intracellular penetration. However, polymeric nanoparticles, when used intravenously, are removed from systemic circulation by the cells of the mononuclear phagocyte system (MPS). Several methods are used to modify the surface of the nanoparticles to avoid recognition and capture by the cells of the MPS and promote a long plasma circulating time and improved pharmacokinetics. Among these methods, coating nanoparticles with hydrophilic polymers such as polyethylene glycol (PEG) is the most popular because the long chains of PEG prevent opsonization and phagocytosis by steric hindrance (Alexis et al., 2008).

To characterize the delivery systems such as polymeric nanoparticles fully, suitable and validated quantitation methods are required to assess pharmaceutical parameters such as drug content. Several methods are described in the literature for the determination of 5-FU in samples of biological matrices using gas chromatography/mass spectrometry (GC/MS) (Anderson et al., 1997), spectrometry (Badea et al., 2002), high performance liquid chromatography (HPLC) (Escoriaza et al., 1999), hydrophilic interaction liquid chromatography-APCI-mass spectrometry (Pisano et al., 2005) or liquid chromatography tandem mass spectrometry (LC-MS/MS) (Licea-Perez, Wang, Bowen, 2009; Liu et al., 2010). The analytical determination of 5-FU in pharmaceutical dosage forms such as nanoparticles has been performed by several authors using spectrophotometry (Bozkir, Saka, 2005; Liu et al., 2006; Zhu et al., 2009; Lai, Guo, 2011; Li et al., 2011; Rejinold et al., 2011a; Rejinold et al., 2011b; Zhang et al., 2011), but few studies report the use of HPLC methods for this determination. Arbós, Campanero and Irache (2002) described an HPLC method for the quantitation of 5-fluorouridine in nanoparticles and verified the possible degradation of 5-FU, but the investigators used a C8 column. Zheng et al (2007) described an HPLC method using as mobile phase a mixture of methanol and $3.6 \%$ acetic acid $(80: 20, \mathrm{v} / \mathrm{v})$, but details such as the retention time, peak characteristics and validation data were not described.

The objective of this work was therefore to develop and validate a fast, simple and optimized HPLC method to determine the encapsulation efficiency of 5-FU incorporated in poly(lactic acid) (PLA) and PLA-PEG blended nanoparticles.

\section{MATERIAL AND METHODS}

\section{Materials}

Fluorouracil (99\% TLC), poly(lactic acid) (PLA) (MW 85-160 kDa), polyethylene glycol (10 kDa) and polyvinyl alcohol (PVA, $31 \mathrm{KDa}, 88 \%$ hydrolyzed) were purchased from Sigma-Aldrich (St. Louis, MO, USA). Methylene chloride was purchased from FMaia ${ }^{\circledR}$ (Brazil). HPLC-grade acetonitrile was purchased from JTBaker ${ }^{\circledR}$ (USA). Water was purified in a Milli-Q Plus system (Millipore $^{\circledR}$ ), and its resistivity was $18.2 \mathrm{M} \mho \mathrm{cm}$. All other solvents and chemicals were analytical or HPLC grade.

\section{Instrumentation}

A Waters 2695 Alliance HPLC system (Milford, MA, USA) was used for method development. The HPLC system was equipped with a column compartment with temperature control, an on-line degasser, a quaternary pump, an auto sampler and a photodiode array (PDA) wavelength detector (Waters 2998). Data acquisition, analysis, and reporting were performed using Empower chromatography software (Milford, MA, USA). HPLC analysis was conducted using a RP C18 column (Xterra Waters ${ }^{\circledR}$ ), with $5 \mu \mathrm{m}$ particle size, $4.6 \mathrm{~mm}$ internal diameter and $250 \mathrm{~mm}$ length.

\section{Preparation of standard and sample solutions}

A stock standard solution of $500 \mu \mathrm{g} / \mathrm{mL}$ of 5 -FU was prepared in water and subsequent dilutions were carried out to obtain eight standard solutions $(0.1,0.5,1.0$, 2.0, 4.0, 6.0, 8.0 and $10.0 \mu \mathrm{g} / \mathrm{mL})$. Similarly, six standard solutions were obtained by serial dilutions of a 5-FU standard solution $(1.0 \mu \mathrm{g} / \mathrm{mL})$ with water $(50.0,75.0,100.0$, $125.0,150.0$, and $200.0 \mathrm{ng} / \mathrm{mL}$ ) to determine the limit of detection (LOD) and limit of quantitation (LOQ) for this 
method. The samples were appropriately diluted in water. The standards and samples had previously been filtered through a $0.22 \mu \mathrm{m}$ pore size filter (Millipore, Bedford, USA) prior to injection.

\section{Chromatographic conditions}

Chromatographic analysis was performed in the isocratic mode. The mobile phase consisted of a mixture of acetonitrile and water $(10: 90, \mathrm{v} / \mathrm{v})$, which was pumped at a flow rate of $1.0 \mathrm{~mL} / \mathrm{min}$. The sample injection volume was $100 \mu \mathrm{L}$, and the PDA detection wavelength was 265 $\mathrm{nm}$. The method run time was $4 \mathrm{~min}$, and all experiments were performed at $25^{\circ} \mathrm{C}$.

\section{Method validation}

The HPLC method was validated according to the International Conference on Harmonization (ICH) guidelines (2005). The following characteristics were considered for validation: specificity, linearity, range, accuracy, precision, LOD, LOQ and robustness.

The specificity was evaluated by comparing the representative chromatograms of samples containing possible interfering substances and samples containing 5-FU. Additionally, specificity was demonstrated by performing stress studies (i.e., light stability, $\mathrm{pH}$ variation, temperature and oxidation).

Linearity was determined by calculating a regression line from the plot of peak area vs. concentration for the eight standard solutions in water (i.e., 0.1, 0.5, 1.0, 2.0, 4.0, 6.0, 8.0 and $10.0 \mu \mathrm{g} / \mathrm{mL}$ ) using the linear least squares methodology.

The accuracy was tested by calculating the percent recovery of the mean concentration of 5-FU at three different concentration levels, and the relative standard deviation (RSD) was determined. The mean concentration value obtained for each level was compared to the theoretical value, which was considered to be $100 \%$.

Precision was assessed at two levels: repeatability or intra-day variability and intermediate precision or inter-day variability. The repeatability was assessed by testing three different standard solutions on the same day and using a standard solution with concentration of 1.0 $\mu \mathrm{g} / \mathrm{mL}$ analyzed 10 times in succession. The results were reported as RSD. The intermediate precision was evaluated by analyzing three different standard samples on two different days. The results were reported as the standard deviation (SD) and RSD.

The LOD and LOQ were determined from the specific calibration curve obtained using six standard solu- tions $(50.0,75.0,100.0,125.0,150.0$, and $200.0 \mathrm{ng} / \mathrm{mL})$ that were the closest to the LOQ. The following equations (1 and 2) were used according to ICH (2005):

$$
\begin{array}{ll}
\mathrm{LOD}=3.3 / \sigma . S & \text { Eq. } 1 \\
\mathrm{LOQ}=10 / \sigma . S & \text { Eq. } 2
\end{array}
$$

where $\sigma$ is the standard deviation of the response, and $\mathrm{S}$ is the slope of the calibration curve.

Robustness was evaluated by deliberately varying the temperature of the analytical column $\left(35^{\circ} \mathrm{C}\right)$, the flow rate $(0.9$ and $1.1 \mathrm{~mL} / \mathrm{min})$ and using a similar $\mathrm{C} 18$ column ( $5 \mu \mathrm{m}$ particle size, $4.6 \mathrm{~mm}$ internal diameter, and $250 \mathrm{~mm}$ length; Vertical Chromatography Co. ${ }^{\circledR}$ ).

\section{Method applicability}

\section{Preparation of 5-FU-loaded PLA or PLA-PEG blended nanoparticles}

The nanoparticles were obtained using the double emulsion solvent-evaporation technique (Zabaux et al., 1998). Initially, PLA was dissolved in methylene chloride either with or without PEG at room temperature. This solution was poured rapidly into a PVA aqueous solution containing 5-FU and emulsified by means of sonication for $1 \mathrm{~min}\left(35 \%\right.$ of $500 \mathrm{~W}$, Unique ${ }^{\circledR}$ Ultrasonic Mixing, mod. DES 500, equipped with a $4 \mathrm{~mm}$ probe, Unique Group, Brazil). The resulting water-in-oil (W/O) emulsion was further emulsified with PVA aqueous solution by sonication for $5 \mathrm{~min}$, resulting in a water-in-oil-in-water emulsion $(\mathrm{W} / \mathrm{O} / \mathrm{W})$. Next, the organic solvent was rapidly eliminated by evaporation under vacuum at $37^{\circ} \mathrm{C}$. The particles were then recovered by ultracentrifugation $(19,975 \mathrm{~g}, 30 \mathrm{~min}$, $4{ }^{\circ} \mathrm{C}$, Cientec CT-15000R centrifuge, Brazil) and washed twice with water to remove the surfactant. The nanoparticles were dispersed in the cryoprotectant sucrose, and the resulting nanosuspension was subsequently cooled to $-18^{\circ} \mathrm{C}$ and freeze-dried (Terroni, Brazil). All details presented here are under patent, as requested in Brazil, and must be protected according to the Brazilian agency regulation.

The mean particle size, size distribution and polydispersity index were determined by dynamic light scattering (BIC 90 plus, Brookhaven Instruments Corp.). The analyses were performed at a scattering angle of $90^{\circ}$ and a temperature of $25^{\circ} \mathrm{C}$. For each sample, the mean particle diameter, polydispersity and standard deviation for ten determinations were calculated.

\section{Determination of the 5-FU encapsulation}

The amount of 5-FU incorporated into the nanopar- 
ticles was determined indirectly (Das Neves et al., 2010). The analyte was the supernatant, which contained free 5-FU separated from solid nanoparticles by ultracentrifugation.

After appropriate dilutions in water, $100 \mu \mathrm{L}$ of the sample was injected into the HPLC system, and the drug concentration in the supernatant was obtained by comparing the concentration obtained to a previously constructed analytical curve. Before injection, all solutions were filtered through a membrane filter $(0.22-\mu \mathrm{m}$ pore size, Millipore). The amount of 5-FU entrapped in the nanoparticles was obtained by subtracting the amount in the supernatant from the total amount used during the preparation. These analyses were performed in triplicate.

\section{RESULTS AND DISCUSSION}

\section{Method development}

Due to the high aqueous solubility of 5-FU, hydro- philic solvents were used to reduce the affinity of the drug for the column and thus obtain short retention times.

Initially, the methodology described in the United States Pharmacopoeia USP34 (2010) was tested, describing ultrapure water as mobile phase, with a rate of $1.0 \mathrm{~mL} / \mathrm{min}$. However, for samples, irregular peaks were observed using low resolution chromatography (Figure 1A), possibly because of instrumental or column differences.

Acetonitrile was added to the mobile phase to improve the resolution of chromatographic peaks of 5-FU. Analyses were performed using acetonitrile and water in many proportions, in isocratic mode and with the proportions of acetonitrile:water ranging from 10:90 $(\mathrm{v} / \mathrm{v})$ to $70: 30(\mathrm{v} / \mathrm{v})$. Noticeable tailing and an irregular shape of the 5-FU peak were observed when the proportion of acetonitrile was higher than the water. Increasing the water proportion in the mobile phase, the 5-FU peak became more regular, and, when the proportion of acetonitrile:water of 10:90 (v/v) was used, a regular and
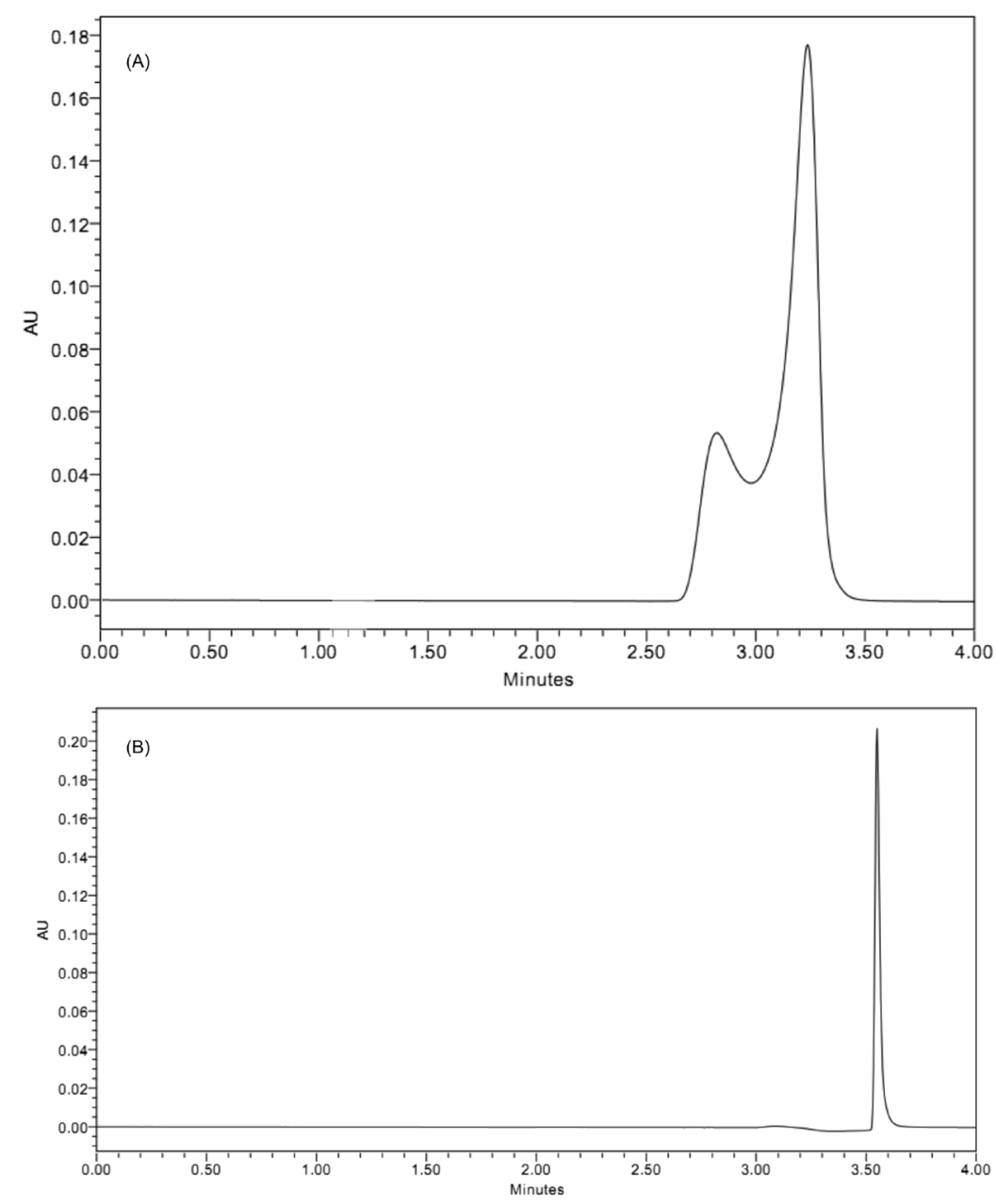

FIGURE 1 - Representative HPLC chromatograms of $1.0 \mu \mathrm{g} / \mathrm{mL}$ 5-FU standard solution, using $100 \%$ ultrapure water as the mobile phase (A) and acetonitrile and water (10:90, v/v) as the mobile phase (B). 
symmetric peak was observed. Under these conditions, the 5-FU peak was detected in approximately $3.5 \mathrm{~min}$ (Figure 1B).

\section{Method validation}

\section{Specificity}

The PVA aqueous solution (i.e., the main component of supernatant obtained by ultracentrifugation of an aqueous dispersion of nanoparticles) was analyzed using the HPLC method described (Figure 2A) and compared with the chromatogram of the 5-FU standard (Figure 1B) and 5-FU sample (5-FU in supernatant) (Figure 2B). A peak at the 5-FU retention time was observed in the chromatogram of the PVA aqueous solution, but the peak is so small that it does not interfere with the quantitative determination of 5-FU from the formulation components. To confirm this observation, a 5-FU standard solution prepared in PVA aqueous solution was analyzed and compared to the 5-FU standard solution in water (as usual). The percent recovery of 5-FU in PVA aqueous solution was 99.89\%.

Tests were also performed under four stress conditions (i.e., temperature, visible light, $\mathrm{pH}$ and oxidation) to detect the occurrence of possible interfering peaks at $265 \mathrm{~nm}$ resulting from the degradation of 5-FU. These tests are regarded as helpful tools in establishing degradation pathways and the inherent stability of the molecule and help validate the power of the method for studying the drug stability (Das Neves et al., 2010). The percent recovery under stress conditions also revealed that 5-FU was not affected, except at high $\mathrm{pH}$ values (4.23\%). The results obtained are presented in Table I, showing no alterations in 5-FU retention time.

\section{Linearity}

Linearity was evaluated at eight concentration levels ranging from 0.1 to $10 \mu \mathrm{g} / \mathrm{mL}$ by calculating the regression equation (Eq. 3) and the correlation coefficient (r) using
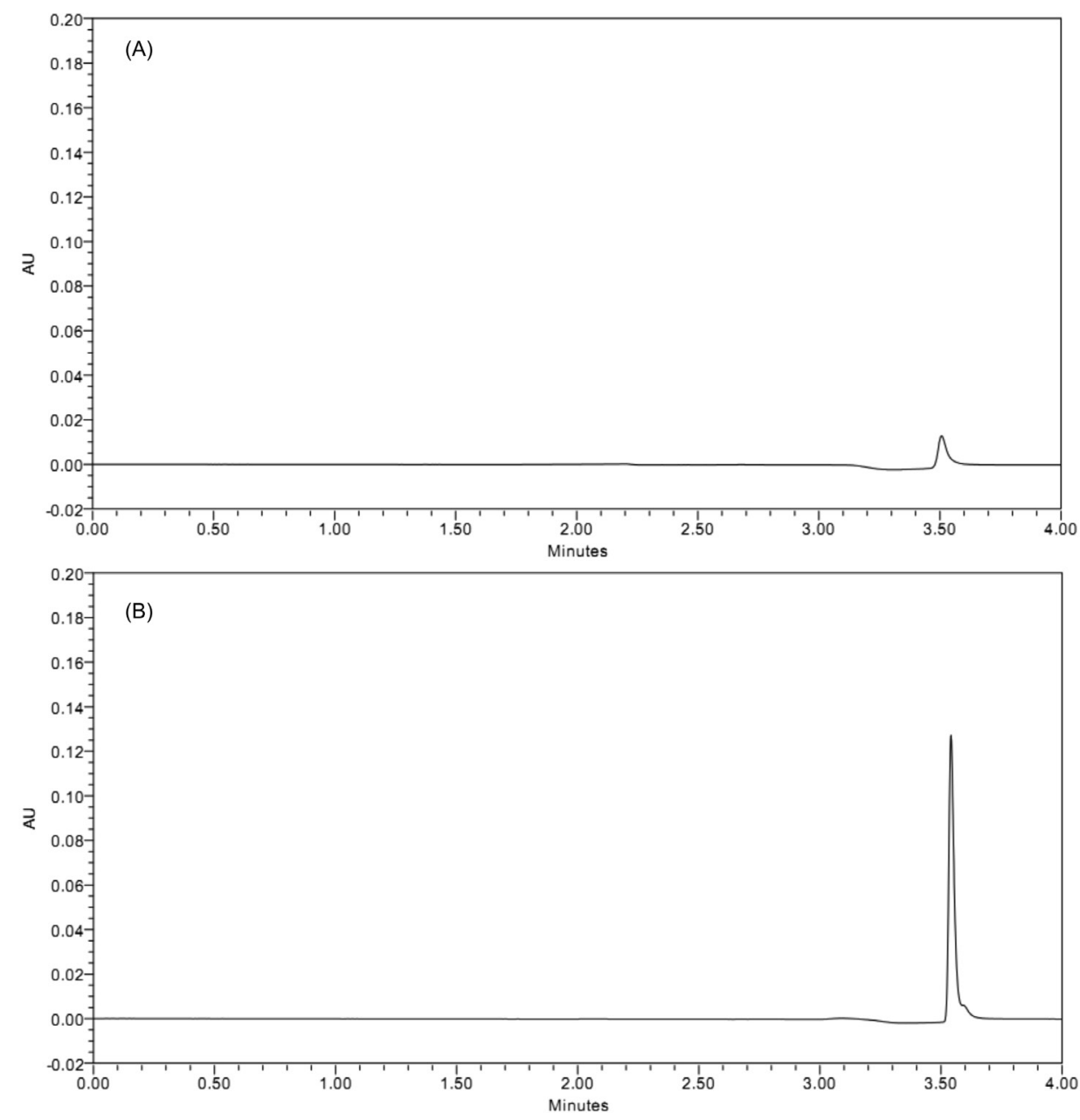

FIGURE 2 - Representative HPLC chromatograms of the PVA aqueous solution (1\% (w/v)) (A) and supernatant from the production of 5-FU nanoparticles (B). 
TABLE I - Results of exposure of 5-FU standards solutions to stress conditions ( $\mathrm{n}=3$ )

\begin{tabular}{lcccc}
\hline \multirow{2}{*}{ Conditions } & \multicolumn{4}{c}{ Percentage of Recovery $\pm \mathrm{RSD}$} \\
\cline { 2 - 4 } & $0.1 \mu \mathrm{g} / \mathrm{mL}$ & $1.0 \mu \mathrm{g} / \mathrm{mL}$ & $10.0 \mu \mathrm{g} / \mathrm{mL}$ & Mean \\
\hline Reference & $99.60 \pm 1.80$ & $104.26 \pm 3.82$ & $104.56 \pm 0.73$ & $102.81 \pm 2.11$ \\
UV light & $104.46 \pm 3.50$ & $107.50 \pm 2.42$ & $103.90 \pm 0.49$ & $105.28 \pm 2.13$ \\
Congealment & $103.30 \pm 2.65$ & $105.36 \pm 0.81$ & $103.20 \pm 1.00$ & $103.95 \pm 1.48$ \\
High pH & $0.00 \pm 35.07$ & $10.36 \pm 38.05$ & $2.33 \pm 38.63$ & $4.23 \pm 37.25$ \\
Low pH & $100.46 \pm 0.32$ & $109.06 \pm 3.61$ & $103.13 \pm 1.05$ & $104.22 \pm 1.66$ \\
Oxidation & $100.46 \pm 0.61$ & $106.23 \pm 1.46$ & $104.60 \pm 0.02$ & $107.09 \pm 0.69$ \\
\hline
\end{tabular}

the method of least squares:

$$
\begin{gathered}
\mathrm{Y}=0.041259 \times \mathrm{A}-4.66 .10^{4} \\
\mathrm{r}=0.9997
\end{gathered}
$$

where $\mathrm{Y}$ is the peak area and $\mathrm{A}$ is the standard solution concentration in $\mu \mathrm{g} / \mathrm{mL}$. The $\mathrm{r}$-value near 1 indicates linearity in the proposed range.

The validity of the assay was confirmed by an analysis of variance, which showed that the linear regression was significant and the deviation from linearity was not significant $(\mathrm{p}<0.01)$.

\section{Accuracy}

Accuracy was assessed by calculating the percent recovery and the RSD of the mean concentration of the analyte at three different concentrations. Three standard solutions $(0.1,1$ and $10 \mu \mathrm{g} / \mathrm{mL})$ were carefully prepared in triplicate and analyzed using the proposed method. Detailed results for these three tested concentration levels are presented in Table II. The mean percent recovery of 5 -FU from the samples was $99.95 \%(\mathrm{RSD}=1.49 \%, \mathrm{n}=9)$. The results show agreement between experimental and theoretical values.

TABLE II - Accuracy results for 5-FU concentrations in the standard solutions

\begin{tabular}{lcc}
\hline $\begin{array}{l}\text { Standard solution } \\
(\mu \mathrm{g} / \mathrm{mL}) *\end{array}$ & Recovery $(\%)$ & RSD $(\%)$ \\
\hline 0.1 & 99.55 & 1.87 \\
1.0 & 98.57 & 0.17 \\
10.0 & 99.71 & 1.27 \\
\hline$* \mathrm{n}=3$ & &
\end{tabular}

\section{Precision}

The precision is a measure of the relative errors of the method, expressed as the RSD for repeatability and intermediate precision. Three concentrations of 5-FU ( 0.1 , 1 and $10 \mu \mathrm{g} / \mathrm{mL}$ ) were prepared in triplicate and analyzed on one day or two different days to evaluate intra-day or inter-day variation, respectively. The RSDs of responses were calculated in each case and are shown in Table III, indicating that precision was obtained because the maximal RSD obtained was 3.51\%.

TABLE III - Precision results for different levels of 5-FU in the standard solutions

\section{Measured}

Standard solution $(\mu \mathrm{g} / \mathrm{mL}) \quad$ concentration \pm SD $\quad$ RSD $(\%)$ $(\mu \mathrm{g} / \mathrm{mL})$

\begin{tabular}{ccc}
\hline $\begin{array}{c}\text { Analysis repeatability }(\mathrm{n}=3) \\
0.1\end{array}$ & $0.09 \pm 0.02$ & 1.87 \\
1.0 & $0.98 \pm 0.00$ & 0.17 \\
10.0 & $9.97 \pm 0.13$ & 1.27 \\
\hline Intermediate precision $(\mathrm{n}=3)$ & & \\
Day 1 & & \\
0.1 & $0.09 \pm 0.00$ & 1.46 \\
1.0 & $0.95 \pm 0.02$ & 2.11 \\
10.0 & $10.14 \pm 0.07$ & 0.70 \\
Day 2 & & \\
0.1 & $0.09 \pm 0.00$ & 1.66 \\
1.0 & $1.04 \pm 0.04$ & 3.51 \\
10.0 & $10.46 \pm 0.07$ & 0.63 \\
\hline
\end{tabular}

The instrumental precision is a measure of the relative errors inherent in the equipment and is expressed as the RSD for repeatability. One standard of 5-FU $(1.0 \mu \mathrm{g} / \mathrm{mL})$ was prepared and analyzed in one day $(\mathrm{n}=10)$. The results indicate the instrument precision (percent recovery $=$ $98.57 \%$ ) because the maximum RSD obtained was $0.13 \%$.

\section{Limits of quantification and detection}

The lowest concentration at which an analyte can 
be detected (LOD) or quantified (LOQ) with acceptable precision and accuracy, in the present study, was calculated from the SD of the response and the slope obtained from linear regression of a specific calibration curve $(50-200 \mathrm{ng} / \mathrm{mL})$ in the low-end region of the proposed range (ICH, 2005). The method was linear in this range because the r-value was 0.993 . The LOD and LOQ were found to be 10.86 and $32.78 \mathrm{ng} / \mathrm{mL}$, respectively.

\section{Range}

The working range of the method, defined as the range that possesses the required linearity, accuracy and precision, was between the LOQ and $10 \mu \mathrm{g} / \mathrm{mL}$. Samples containing these concentration levels may therefore be assayed using the proposed HPLC method.

\section{Robustness}

Robustness is a measure of the influence of small changes in the analytical procedures/parameters on the response. The evaluation of robustness was based on the percent recovery and RSD values obtained using different parameters for flow rate of mobile phase and column temperature and using a similar $\mathrm{C} 18$ column. The method is robust concerning these alterations in chromatographic parameters (Table IV). The maximum RSD obtained was $3.48 \%$.

\section{Method applicability}

The proposed analytical method was used to evaluate the content of 5-FU in PLA and PLA-PEG blended nanoparticles. An indirect method, which separated the supernatant containing free 5-FU from the solid nanoparticles by ultracentrifugation, was used. The supernatant was analyzed using HPLC. As shown in the specificity test, no alterations to the chromatograms or unusual peaks were observed during the drug quantification.

The method of double emulsion-solvent evaporation was adequate to obtain the nanoparticles containing 5-FU. The main characteristics of the nanoparticles are described in Table V. The presence of PEG did not influence the encapsulation efficiency because both nanoparticles showed the same efficiency in loading the 5-FU. Considering the particle size, the PEG provided a slight increase in particle size compared with PLA nanoparticles $(p<0.05)$, but both formulations presented a bimodal distribution profile. Nanoparticles can be considered potential carriers for 5-FU delivery.

Our objective was to develop a fast, simple and effective HPLC-PDA method for quantitative analyses of 5-FU in PLA and PLA-PEG blended nanoparticles. The literature describes mainly spectrophotometric methods for 5-FU quantitation in nanoformulations (Bozkir, Saka,

TABLE IV - Robustness results for different flow rate, column brand and temperature

\begin{tabular}{lcccc}
\hline $\begin{array}{l}\text { Changes to original } \\
\text { method* }\end{array}$ & \multicolumn{3}{c}{ Percentage of Recovery $\pm \mathrm{RSD}$} \\
\cline { 2 - 4 } & $0.1 \mu \mathrm{g} / \mathrm{mL}$ & $1.0 \mu \mathrm{g} / \mathrm{mL}$ & $10.0 \mu \mathrm{g} / \mathrm{mL}$ & Mean \\
\hline None & $99.55 \pm 1.87$ & $98.57 \pm 0.17$ & $99.71 \pm 1.27$ & $99.28 \pm 1.10$ \\
Flow rate: $0.9 \mathrm{~mL} / \mathrm{min}$ & $104.80 \pm 3.48$ & $103.53 \pm 2.22$ & $99.23 \pm 1.76$ & $102.52 \pm 2.48$ \\
Flow rate: $1.1 \mathrm{~mL} / \mathrm{min}$ & $107.36 \pm 3.44$ & $102.40 \pm 2.30$ & $100.40 \pm 1.05$ & $103.38 \pm 2.27$ \\
Similar column & $97.33 \pm 0.01$ & $105.50 \pm 0.06$ & $106.56 \pm 0.65$ & $103.13 \pm 0.24$ \\
Column Temperature: & $98.43 \pm 0.00$ & $105.90 \pm 0.04$ & $97.85 \pm 0.77$ & $100.72 \pm 0.27$ \\
$35^{\circ} \mathrm{C}$ & & & \\
\hline
\end{tabular}

* $1.0 \mathrm{~mL} / \mathrm{min}$, column at $25^{\circ} \mathrm{C}$ and mobile phase (acetonitrile:water 10:90, v/v).

TABLE V - Nanoparticle characteristics

\begin{tabular}{|c|c|c|c|c|}
\hline Nanoparticle & Mean size $(\mathrm{nm})^{\mathrm{a}}$ & Polydispersity index ${ }^{a}$ & Size distribution ${ }^{\mathrm{a}}$ & $\begin{array}{l}\text { Encapsulation } \\
\text { efficiency }(\%)^{\mathrm{a}}\end{array}$ \\
\hline PLA & $282.87 \pm 3.64$ & 0.116 & $195-233 \mathrm{~nm}(54 \%)$ and $398-476 \mathrm{~nm}(46 \%)$ & $51.23 \pm 7.82$ \\
\hline PLA-PEG & $305.80 \pm 3.62$ & 0.173 & $171-208 \mathrm{~nm}(39 \%)$ and $432-525 \mathrm{~nm}(61 \%)$ & $55.53 \pm 9.21$ \\
\hline
\end{tabular}

${ }^{\text {a }}$ Values reported as mean \pm S.D. $(n=3)$. 
2005; Liu et al., 2006; Zhu et al., 2009; Lai, Guo, 2011; Li et al., 2011; Rejinold et al., 2011a; Rejinold et al., 2011b; Zhang et al., 2011), but these methods are not as convenient as HPLC methods considering the sensitivity. The only example in the literature of an HPLC-UV method applied to 5-FU determination in nanoparticles was the method cited by Zheng et al. (2007), but the authors cited only the mobile phase (methanol:3.6\% acetic acid - 80:20, $\mathrm{v} / \mathrm{v}$ ) and did not give any information about validation data and retention time of 5-FU. Arbós, Campanero and Irache (2002) developed an HPLC-UV method for quantitation of 5 -fluorouridine in nanoparticles and, in addition to other parameters, verified whether this drug degrades in 5-FU. The mobile phase was comprised of $0.05 \mathrm{M}$ ammonium acetate ( $\mathrm{pH}$ 6.5), and the results showed a retention time of $6.7 \mathrm{~min}$ for 5 -fluorouridine and $4.5 \mathrm{~min}$ for 5 -FU. The method was sensitive and could be applied to 5-FU, but a C8 column was used, so the method does not correspond to our chromatographic conditions. Thus, the HPLC-PDA method developed and validated in this work represents an alternative to spectrophotometric methods for the analysis of 5-FU in nanoparticles and fulfills the requirement for detailed data in the literature for analyzing 5-FU in nanoparticles via HPLC-PDA detection. The proposed method could be applied not only for the determination of encapsulation efficiency of 5-FU in nanoparticles but also for other assays, such as determining the in vitro 5-FU release profile and stability studies.

\section{CONCLUSION}

A fast, simple and reliable HPLC method using photodiode array detection for determining the encapsulation efficiency of 5-FU in PLA and PLA-PEG blended nanoparticles has been developed and validated according to the ICH guidelines. The method fulfilled the requirements to be considered a reliable and feasible method, including specificity, linearity, precision, accuracy, robustness, LOD and LOQ. The analytical procedure has a chromatographic run time of $4 \mathrm{~min}$, which allows analyzing a large number of samples in a short period of time. The low percentage of acetonitrile used is important because it reduces the cost of solvent and the damage to the environment. This method was found to be suitable for determining 5-FU encapsulation efficiency in polymeric nanoparticles.

\section{ACKNOWLEDGMENTS}

This study was supported by CAPES (scholarship).

\section{REFERENCES}

AKAGI, T.; KANEKO, T.; KIDA, T.; AKASHI, M. Preparation and characterization of biodegradable nanoparticles based on poly (g-glutamic acid) with 1-phenylalanine as a protein carrier. J. Control. Release, v.108, n.2-3, p.226-236, 2005.

ALEXIS F.; PRIDGEN E.;MOLNAR, L.K.;FAROKHZAD, O.C. Factors affecting the clearance and biodistribution of polymeric nanoparticles. Mol. Pharm., v.5, n.4, p.505-515, 2008.

ANDERSON, D.; KERR, D.J.; BLESING, C.; SEYMOUR, L.W. Simultaneous gas chromatographic-mass spectrophotometric determination of a-fluoro-P-alanine and 5-fluorouracil in plasma. J. Chromatogr. B, v.688, n.1, p.87-93, 1997.

ARBÓS, P.; CAMPANERO, M.A.; IRACHE, J.M. RP-LC determination of 5 -fluorouridine in nanoparticulate formulations. J. Pharm. Biomed. Anal., v.28, n.5, p.857866, 2002.

BADEA, I.; MOJA, D.; TUDOSE, A.; STOICESCU, D. Determination of the 5-fluorouraciland N1(2?-furanidyl) uracil in the presence of tegafur by zero-crossing first derivative spectrometry. J. Pharm. Biomed. Anal., v.30, n.4, p.1371-1378, 2002.

BOZKIR, A.; SAKA, O.M. Formulation and investigation of 5-FU nanoparticles with factorial design-based studies. Farmaco, v.60, n.10, p.840-846, 2005.

CASALE, F., CANAPARO, R; SERPE, L.; MUNTONI, E.; PEPA, C.D; COSTA, M.; MAIRONE, L.; ZARA, G.P.; FORNARI, G.; EANDI, M. Plasma concentrations of 5 -fluorouracil and its metabolites in colon cancer patients. Pharmacol. Res., v.50, n.2, p.173-179, 2004.

DAS NEVES, J.; SARMENTO, B.; AMIJI, M.M.; BAHIA, M.F. Development and validation of a rapid reversed-phase HPLC method for the determination of the non-nucleoside reverse transcriptase inhibitor dapivirine from polymeric nanoparticles, J. Pharm. Biomed. Anal., v.52, n.2, p.167$172,2010$.

ESCORIAZA, J.; ALDAZ, A.; CALVO, E.;GIRÁLDEZ, J. Simple and sensitive determination of 5-fluorouracil in plasma by high-performance liquid chromatography. Application to clinical pharmacokinetic studies. $J$. Chromatogr. B, v.736, n.1-2, p.97-102, 1999. 
GAMELIN, E., BOISDRON-CELLE, M. Dose monitoring of 5-fluorouracil in patients with colorectal or head and neck cancer - status of the art. Crit. Rev. Oncol. Hemat., v.30, n.1, p.71-79, 1999.

GAMELIN, E.; BOISDRON-CELLE, M.; GUÉRIN-MEYER, V.; DELVA, R.; LORTHOLARY, A.; GENEVIEVE, F. Correlation between uracil and dihydrouracil plasma ratio, fluorouracil (5-FU) pharmacokinetic parameters, and tolerance in patients with advanced colorectal cancer: a potential interest for predicting 5-FU toxicity and determining optimal 5-FU dosage. J. Clin. Oncol., v.17, n.4, p.1105-1110, 1999.

GREM, J.L. Fluorinated pyrimidines. In: CHABNER, B.A.; COLLINS, J.M. (Eds.) Cancer chemotherapy: principles and practice. Philadelphia: J.B. Lippincott, 1990. p.180224.

INTERNATIONAL CONFERENCE ON HARMONISATION OF TECHNICAL REQUIREMENTS FOR REGISTRATION OF PHARMACEUTICALS FOR HUMAN USE. ICH HARMONISED TRIPARTITE GUIDELINE: Validation of Analytical procedures: text and methodology Q2(R1), 2005, p. 1-13.

LABHASETWAR, V.; PRABHA, S. Nanoparticle-mediated wild-type p53 gene delivery results in sustained antiproliferative activity in breast cancer cells. Mol. Pharm., v.1, n.3, p.211-219, 2004.

LAI, L.F.; GUO, H.X. Preparation of new 5-fluorouracil-loaded zein nanoparticles for liver targeting. Int. J. Pharm., v.404, n.1-2, p.317-323, 2011.

LI, P.; WANG, Y.; PENG, Z.; SHE, F.; KONG, L. Development of chitosan nanoparticles as drug delivery systems for 5-fluorouracil and leucovorin blends. Carbohyd. Polym., v.85, n.3, p.698-704, 2011.

LICEA-PEREZ, H.; WANG, S.; BOWEN, C. Development of a sensitive and selective LC MS/MS method for the determination of $\alpha$-fluoro- $\beta$-alanine, 5 -fluorouracil and capecitabine in human plasma. J. Chromatogr. B, v.877, n.11-12, p.1040-1046, 2009.

LIU, L.; JIN, P.; CHENG, M.; ZHANG, G. ;ZHANG, F. 5-Fluorouracil-loaded self assembled ph-sensitive nanoparticles as novel drug carrier for treatment of malignant tumors. Chinese J. Chem. Eng., v.14, n.3, p.377382, 2006.
LIU, K.; ZHONG, D.; ZOU, H.; CHEN, X. Determination of tegafur, 5-fluorouracil, gimeracil and oxonic acid in human plasma using liquid chromatography-tandem mass spectrometry. J. Pharm. Biomed. Anal., v.52, n.4, p.550$556,2010$.

MOGHIMI, S.M.; HUNTER, A.C.; MURRAY, J.C. Longcirculating and target specific nanoparticles: theory to practice. Pharmacol. Rev., v.53, p.283-318, 2001.

PANYAM, J.; LABHASETWAR, V. Biodegradable nanoparticles for drug and gene delivery to cells and tissue. Adv. Drug Deliver. Rev., v.55, n.3, p.329-347, 2003.

PETERS, G.J.; VAN GROENINGEN, C.J. Clinical relevance of biochemical modulation of 5-fluorouracil. Ann. Oncol., v.2, n.7, p.469-480, 1991.

PINEDO, H.M.; PETERS, G.F. Fluorouracil: biochemistry and pharmacology. J. Clin. Oncol., v.6, n.10, p.1653-1664, 1988.

PISANO, R.; BREDA, M.; GRASSI, S.; JAMES, C.A. Hydrophilic interaction liquid chromatography-APCI-mass spectrometry determination of 5-fluorouracil in plasma and tissues. J. Pharm. Biomed. Anal., v.38, n.4, p.738-745, 2005.

REJINOLD, N.S.; CHENNAZHI, K.P.; NAIR, S.V.; TAMURA, H.; JAYAKUMAR, R. Biodegradable and thermo-sensitive chitosan-g-poly(N-vinylcaprolactam) nanoparticles as 5-fluorouracil Carrier. Carbohyd. Polym., v.83, n.2, p.776786, 2011a.

REJINOLD, N.S.; MUTHUNARAYANAN, M.; CHENNAZHI, K.P.; NAIR, S.V.; JAYAKUMAR, R. 5-Fluorouracil loaded fibrinogen nanoparticles for cancer drug delivery application. Int. J. Biol. Macromol., v.48, n.1, p.98-105, 2011b.

TANAKA, F.; FUKUSE, T.; WADA, H.; FUKUSHIMA, M. The history, mechanism and clinical use of oral 5-fluorouracil derivative chemotherapeutic agents. Curr. Pharm. Biotech., v.1, n.2, p.137-164, 2000.

UNITED STATES PHARMACOPEIA. USP 34: The National formulary: NF 29: by authority of the United States Pharmacopeia Convention prepared by the council of experts and its expert committees. 29.ed. Rockville: United States Pharmacopeia Convention, 2010. v.2, p.2874-2875. 
ZHANG, Y.; LI, J.; LANG, M.; TANG, X.; LI, L.; SHEN, $\mathrm{X}$. Folate-functionalized nanoparticles for controlled 5-Fluorouracil delivery. J. Colloid Interf. Sci., v.354, n.1, p.202-209, 2011.

ZHENG, Y.; YANG, W.; WANG, C.; HU, J.; FU, S.; DONG, L.; WU, L.; SHEN, X. Nanoparticles based on the complex of chitosan and polyaspartic acid sodium salt: Preparation, characterization and the use for 5-fluorouracil delivery. Eur. J. Pharm. Biopharm., v.67, n.3, p.621-631, 2007.

ZHU, L.; MA, J.; JIA, N.; ZHAO, Y.; SHEN, H. Chitosancoated magnetic nanoparticles as carriers of 5-Fluorouracil: Preparation, characterization and cytotoxicity studies. Coll. Surf. B, v.68, n.1, p.1-6, 2009.
ZAMBAUX, M.F.; BONNEAUX, F.; GREF, R.; MAINCENT, P.; DELLACHERIE, E.; ALONSO, M.J.; LABRUDE, P.; VIGNERON, C. Influence of experimental parameters on the characteristics of poly(lactic acid) nanoparticles prepared by a double emulsion method. J. Control. Release, v.50, n.1-3, p.31-40, 1998.

Received for publication on $28^{\text {th }}$ May 2012 Accepted for publication on $25^{\text {th }}$ October 2012 